\title{
PLAUČIU巳 FUNKCIJOS VAIZDAVIMAS ELEKTRINIO IMPEDANSO TOMOGRAFIJA: KLINIKINIS TAIKYMAS
}

\author{
Ernestas Viršilas ${ }^{1,3}$, Adomas Janulionis ${ }^{1,3,4}$, Arūnas Liubšys ${ }^{1,3}$, Arūnas Valiulis ${ }^{1,2,3,4}$ \\ ${ }^{1}$ Vilniaus universiteto Medicinos fakulteto Klinikinès medicinos instituto Vaiku ligu klinika, \\ ${ }^{2}$ Vilniaus universiteto Medicinos fakulteto Sveikatos moksly institutas, \\ ${ }^{3}$ Vaiku ligonine, Vilniaus universiteto ligoninès Santaros kliniku filialo Neonatologijos centras, \\ ${ }^{4}$ Vilniaus miesto klinikinès ligoninès Vaiku ligu klinika
}

Raktažodžiai: dirbtinis kvėpavimas, elektrinio impedanso tomografija, naujagimiai, naujagimių kvèpavimo sutrikimo sindromas, ūminis (suaugusiųjų) kvėpavimo sutrikimo sindromas.

\begin{abstract}
Santrauka
Kvėpuojamajai plaučių funkcijai vertinti ilgą laiką buvo taikomi netiesioginiai arba invazyvūs metodai, kurie stokojo tikslumo, rodè plaučių būklę tik tam tikru momentu ir (arba) skleide jonizuojančiają spinduliuotę. Elektrinio impedanso tomografija (toliau - EIT) - dar naujas, neinvazyvus metodas, leidžiantis realiu laiku vertinti ir stebèti plaučių aeraciją, nekeliant pavojaus paciento sveikatai. Tobulejjant EIT technologijai, šis metodas, vis plačiau taikomas suaugusiujų, vidurinio amžiaus vaikų ir paauglių klinikinèje praktikoje, skinasi kelią ị kasdienę naujagimių gydymo ir slaugos praktiką. Šios studijos tikslas - plačiau supažindinti skaitytojus su EIT metodu ir jo taikymu klinikinëje praktikoje. Straipsnių paieška atlikta Pubmed duomenų bazèje, atrinkti tinkamiausi ir panaudoti apžvalgoje. Tyrimo apibendrinimas: EIT realiu laiku teikia informaciją apie regioninę plaučiu aeraciją, padeda nustatyti plaučiuose vykstančius pokyčius ir igalina laiku parinkti pacientui tinkamiausią kvėpuojamają terapiją. EIT metodo taikymas teikia galimybę laiku nustatyti ir pašalinti ūmias komplikacijas, gauti vertingos informacijos apie lètinius procesus plaučiuose bei jų gydymą.
\end{abstract}

\section{Ivadas}

Elektrinio impedanso tomografija - neinvazyvus metodas, neskleidžiantis apšvitos, teikiantis galimybę prie ligonio lovos realiu laiku vertinti ir stebèti plaučių aeraciją, nekeliant pavojaus sveikatai. Nors EIT klinikineje praktikoje pradèta taikyti daugiau nei prieš 30 metu [1], tačiau tik pastaruoju dešimtmečiu, kai buvo siekiama sumažinti spinduliuojančios radiacijos poveikị vertinant paciento plaučių būklę ir kvèpuojamosios terapijos efektyvumą, šis metodas susilauke daugiau dèmesio. EIT vis dažniau taikomas visų amžiaus grupių pacientams intensyviosios terapijos skyriuose, ypač kai nuolat reikia vertinti paciento plaučių būklę, daryti dirbtinį kvejpavimą ar taikyti kitus pagalbinio kvépavimo būdus, atlikti ịvairias slaugos procedūras, keisti sunkiai sergančiojo padètį ir pan. EIT gali būti labai naudinga, kai reikia parinkti tinkamiausią nuolatinị teigiamą kvėpavimo takų slègị, keisti pagalbinio kvèpavimo būdus ar režimus, stebėti taikomo gydymo poveikị skirtingoms plaučių dalims [2-4]. EIT ịgyja pripažinimą ne tik ūminių būklių, tokių kaip suaugusiųjų kvèpavimo sutrikimo sindromas ar pneumonija, gydymo atvejais. Ji taikoma vertinti ligos eigą, ar numatyti letinių ligų, tokių kaip cistinė fibrozė ar obstrukcinè plaučių liga, prognozę [5,6]. Pradejjusi savo kelią mokslinių tyrimų centruose, EIT greitai tapo prieinama ir populiari įvairių šalių ir ligoninių specializuotuose skyriuose [7]. Neseniai pradetas specialių diržų-elektrodų taikymas naujagimiams, atvėrẻ EIT kelią ir ị naujagimių skyrius. Nors EIT aukštos skiriamosios gebos erdvinių vaizdų kokybė neprilygsta kompiuterinès tomografijos (toliau - KT) ar magnetinio rezonanso tomografijos vaizdų kokybei, tačiau EIT teikia galimybę dinamiškai stebèti paciento plaučių būklę tiesiog prie jo lovos, neskleidžia radioaktyviosios spinduliuotès. EIT vaizdų kokybę gali prastinti paciento judesiai, netinkamas elektrodų kontaktas su oda ar kitų medicinos prietaisų keliami trikdžiai [8]. Skirtingų plaučių būklès vertinimo būdų palyginamoji charakteristika pateikiama 1 lentelèje.

Darbo tikslas - plačiau supažindinti medikų bendruomenę su EIT, jos veikimo principais, privalumais ir trūkumais, klinikinio taikymo galimybėmis visų amžiaus grupių pacientams, įskaitant naujagimius. 
1 lentelè. EIT ir kitų plaučių monitoravimo metodų palyginimas.

$\mathrm{a}$ - Tyrimui reikalingas pakartotinis ligonio išguldymas ir slaugos manipuliacijos; b - atliekama tik sąmoningiems ir kooperatyviems ligoniams, c - naudojant kontrastą.

\begin{tabular}{|c|c|c|c|c|c|c|}
\hline Metodika & $\begin{array}{c}\text { Ligonio } \\
\text { transporta- } \\
\text { vimas }\end{array}$ & $\begin{array}{l}\text { Invazy- } \\
\text { vus }\end{array}$ & Apšvita & Matavimas & $\begin{array}{c}\text { Laiko } \\
\text { skiriamoji } \\
\text { geba }\end{array}$ & $\begin{array}{l}\text { Erdvinè } \\
\text { skiriamoji } \\
\text { geba }\end{array}$ \\
\hline Plaučių ultragarsas & $\mathrm{Ne}$ & $\mathrm{Ne}$ & $\mathrm{Ne}$ & Statinis & Taip $^{\mathrm{a}}$ & Taip (2D) \\
\hline Spirometrija & $\mathrm{Ne}^{\mathrm{b}}$ & $\mathrm{Ne}$ & $\mathrm{Ne}$ & Statinis & Dalinè & - \\
\hline Pletizmografija & Taip & Dalinai & $\mathrm{Ne}$ & Statinis & $\mathrm{Ne}$ & - \\
\hline Kraujo dujų tyrimas & $\mathrm{Ne}$ & Taip & $\mathrm{Ne}$ & Statinis & $\mathrm{Ne}$ & - \\
\hline $\begin{array}{l}\text { Pozitronų emisijos } \\
\text { tomografija }\end{array}$ & Taip & Taip ${ }^{c}$ & Taip & Statinis & $\mathrm{Ne}$ & Taip (3D) \\
\hline $\begin{array}{l}\text { Magnetinio rezonanso } \\
\text { tomografija }\end{array}$ & Taip & $\mathrm{Ne}$ & $\mathrm{Ne}$ & Statinis/Nuolatinis & $\mathrm{Ne}$ & Taip (3D) \\
\hline $\begin{array}{l}\text { Kompiuterinè } \\
\text { tomografija }\end{array}$ & Taip & Taip ${ }^{c}$ & Taip & Statinis/Nuolatinis & $\mathrm{Ne}$ & Taip (3D) \\
\hline $\begin{array}{l}\text { Krūtinès ląstos } \\
\text { rentgenograma }\end{array}$ & $\mathrm{Ne}$ & $\mathrm{Ne}$ & Taip & Statinis & $\mathrm{Ne}$ & Taip (2D) \\
\hline $\begin{array}{l}\text { Elektrinio impedanso } \\
\text { tomografija }\end{array}$ & $\mathrm{Ne}$ & $\mathrm{Ne}$ & $\mathrm{Ne}$ & Nuolatinis & Taip & Taip (2D) \\
\hline
\end{tabular}

\section{Medžiaga ir metodai}

Naudotasi Pubmed duomenų baze, JAV Nacionalinès medicinos bibliotekos medicinos terminų tezauru ir nacionalinių sveikatos institutų publikacijomis. Straipsniai tyrimui rinkti naudojant MeSH (angl. Medical subject heading) duomenų bazès terminus ir frazes bei jungtukus ,ar“, ,ir“ (angl. and, or), pvz., „elektrinis impedansas“ ar ,elektrinio impedanso tomografija“ ir ,plaučių“. Paieška, atlikta iki 2019 m. rugpjūčio mėnesio, aprèpia 35 metų laikotarpi. Tyrimai, matuojan-

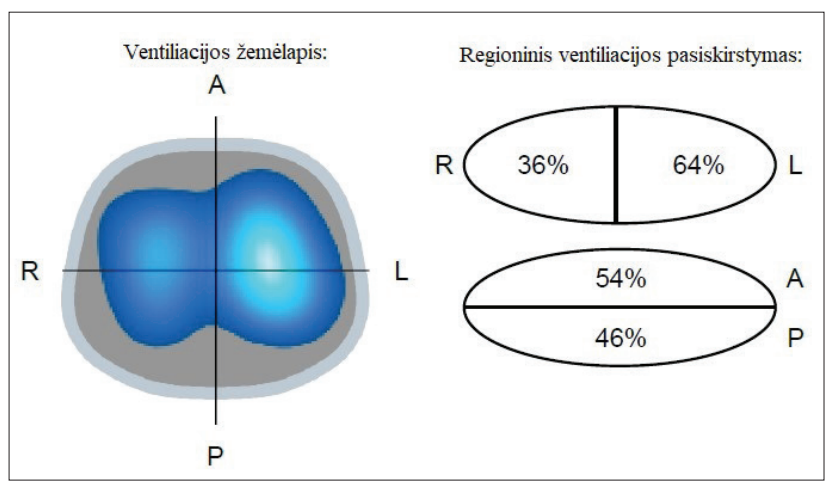

1 pav. EIT plaučių ventiliacijos žemėlapis ir regioninis ventiliacijos pasiskirstymas. Paveiksle matoma sumažèjusi dešinio plaučio ventiliacija dèl kvẻpavimo takų sekreto. A - priekinis krūtinès ląstos paviršius, $\mathrm{P}$ - užpakalinis krūtinès ląstos paviršius, $\mathrm{R}$ - dešinė, $\mathrm{L}$ - kairè. tys plaučių kraujotaką naudojant EIT, ị apžvalgą neịtraukti dèl plaučių perfuzijos stebėsenai reikalingos metodikos [9] (hipertoninio $\mathrm{NaCl}$ tirpalo suleidimo ị centrinę veną) ir kol kas neicvardinto klinikinio pritaikymo vaikams. Neįtraukti tyrimai su gyvūnais.

EIT veikimo principas pagrịstas elektrinès varžos matavimu tarp dviejų elektrodų. 16 elektrodų diržas, juosiantis krūtinès ląstą, leidžia matuoti varžą skirtinguose taškuose, apimdamas abu plaučius. Iš vieno elektrodo skleidžiamas mažosios srovès impulsas (5 mA), o kiti elektrodai registruoja įtampos kitimą skirtingose plaučiu vietose. İkvėpimo metu oras patenka ị plaučius, išsiplečia krūtinès ląsta, todèl pakinta audinių varža, matuojama tarp elektrodų porų. Matuojant audinių varžos kitimą, registruojami audinių tankio pakitimai, kurie nenutrūkstamai keičiami funkciniais vaizdais, o šie, būdami skirtingo intensyvumo atspalvių, rodomi prietaiso ekrane. Ekrane galima matyti skaitines varžų pokyčių reikšmes ir jų diagramas. Geriausiai aeruojamos plaučių dalys yra šviesesnès, mažiau - tamsesnès. Matant vaizdus, nesunkiai galima spręsti, kuriose plaučių dalyse aeracija nevyksta, arba ji nepakankama (pvz., plaučių atelektazė, skysčiu užpildytos dalys ir pan.). EIT metodu galima nuolat stebèti plaučių būklę realiu laiku $[8,10]$. Nors EIT tiesiogiai nematuoja plaučių tūrio, o vertinamas tik reliatyvus varžų pokytis, iš gautujų duomenų sukurta plaučių pletizmograma (1 pav.) teikia daug informacijos apie plaučiu ir jo dalių ventiliaciją. Šiuo metu i EIT prietaisus integruojamas oro 
tėkmės jutiklis, kuris, prijungtas prie ligonio kvėpuojamojo kontūro, teikia informaciją apie kvèpavimo slègị, tūrị, kitus kvèpavimo parametrus [11]. Tékmès jutiklis $2 \mathrm{ml}$ padidina negyvaji tarpą, kuris suaugusiojo kvèpavimui didesnès įtakos neturi, tačiau gali viršyti giliai neišnešiotų naujagimiu kvėpuojamajị tūrị. Tèkmès jutiklis gali būti naudojamas tik tiems pacientams, kuriems taikomas dirbtinis kvejpavimas per intubacinį vamzdelị. Neinvazyvios kvejpuojamosios terapijos atveju ị paciento kvèpuojamaji kontūrą integruoti oro tèkmès jutiklio neimanoma.

Klinikinis EIT taikymas suaugusiesiems, vidurinio amžiaus vaikams ir paaugliams. EIT taikymas klinikinèje praktikoje dažniausiai yra trejopas: 1) plaučių būklès vertinimas mechaninès plaučiu ventiliacijos metu, 2) plaučių funkcijos tyrimas ir 3) širdies veiklos bei plaučių kraujotakos vertinimas. EIT tyrimas realiu laiku prie ligonio lovos teikia vertingą klinikinę informaciją, kurios neįmanoma gauti kitais tyrimo metodais. Daugelis klinikinių tyrimų patvirtina, kad EIT informacija prilygsta KT $[12,13]$, pozitronų emisijos tomografijos [14] ir spirometrijos $[15,16]$ duomenims.

Üminis (suaugusiųjų) kvẻpavimo sutrikimo sindromas (angl. acute respiratory distress syndrome, toliau - ARDS) - viena iš sudètingiausių būklių, kurios metu greitai progresuoja kvėpavimo nepakankamumas dèl alveolių edemos, susiformuojančios esant plaučių kraujagyslių endotelio ir alveolių epitelio pažeidimui [17]. Šiems ligoniams dažniausiai tenka taikyti didelių parametrų dirbtinį kvẻpavimą, dèl kurio neretas antrinis, su mechanine ventiliacija susijęs, plaučių pažeidimas. Tinkamai parinkti dirbtinio kvejpavimo parametrus nèra paprasta, nes siekiama garantuoti reikiamą oksigenaciją ir ventiliaciją, kuo mažiau pažeidžiant plaučius. Naudojant EIT, galima matyti atskirų plaučių dalių aeraciją, t.y. pertemptas ir subliuškusias dalis, prie ligonio lovos parinkti tinkamiausius ventiliacijos parametrus, pasiekti plaučių ventiliacijos homogeniškumo ir sumažinti mirštamumą [18]. EIT pagalba galima parinkti slègị, reikalingą atverti alveoles ir, baigus parinkimo procedūrą, tą slègi palaikyti [2]. Yra duomenu, kad per didelis liekamasis teigiamas slègis iškvejpimo pabaigoje (angl. Positive end expiratory pressure, toliau - PEEP) sukelia plaučiu pertempimą, kuris sunkina širdies darbą, gali sukelti oro nuosruvị (pvz., pneumotoraksą, pneumomediastinumą ar poodinę emfizemą), o dèl per mažo PEEP galimos plaučių atelektazès. EIT ne tik padeda matyti plaučiu aeraciją, naudojant skirtingą PEEP, bet igalina parinkti tinkamiausią slègi, garantuojantị labiausiai homogenišką plaučių ventiliaciją. Jokiais kitais šiuo metu žinomais metodais nebuvo galima to padaryti [19]. Kai kurie EIT prietaisai (pvz. Enlight 1800, Timpel, Brazil) turi integruotą automatinę PEEP nustatymo funkciją, kurios pagalba gydytojas parenka labiausiai tinkamą reikšmę [20].
Pneumonija - plaučių audinio uždegimas, dažniausiai sukeliamas bakterijų (rečiau virusų ir grybelių). Visuomenėje igyta pneumonija yra viena iš dažniausių hospitalizacijos, sergamumo ir mirtingumo priežasčių Lietuvoje [21] ir Europoje [22]. Inprasta, kad uždegimo laipsniui ir vietai nustatyti, susikaupusiam skysčiui ar kitoms komplikacijoms išsiaiškinti dažniausiai atliekama krūtinès ląstos rentgenograma. EIT galètų būti naudinga ne tik infiltracinių plaučių pokyčių vietai ir dydžiui nustatyti, bet ir dinaminių ventiliacijos pokyčių vertinimui gydymo laikotarpiu [23].

Lètinè obstrukcinė plaučių liga (toliau - LOPL) labai paplitusi tarp įvairaus, ypač vyresnio amžiaus grupès, pacientų. Ligai būdingas lètinis bronchų uždegimas ir jų obstrukcija. Ligos sunkumui ir plaučių funkcijai įvertinti dažniausiai naudojama spirometrija, kuri matuoja funkcinị plaučių tūrị ir talpą. Tą pati galima padaryti pasitelkus funkcinius EIT vaizdus. EIT gali suteikti ir kitos vertingos informacijos: parodyti netolygų plaučių oringumą, ligonio atsaką į bronchodilatacinį mėgini ar kitą gydymą, padèti fenotipuoti pacientus, numatyti ligos eigą ir prognozę [5].

Cistinè fibrozė - tai autosominiu recesyviniu būdu paveldima liga, dažniausiai pasireiškianti lètine kvėpavimo takų infekcija, sukeliančia smulkiųjų kvėpavimo takų uždegimą ir obstrukciją. Ilgainiui vystosi bronchektazès ir LOPL [24]. Diagnozei nustatyti ir jos eigai ịvertinti dažniausiai naudojamas radiologinis tyrimas - KT, tačiau dèl apšvitos jis nera tinkamas ilgalaikiam ir nuolatiniam ligos vertinimui. Pasitelkus EIT, galima įvertinti didžiausią iškvejpimo srovès greitį (angl. maximum expiratory force, sutr. MEF) bei funkcinę plaučių talpą, nustatyti plaučių obstrukcijos vietas, parodančias bronchektazes ir (arba) peribronchinių audinių sustorejjimą. EIT metu gaunami duomenys gerai koreliuoja su šiuo metu priimtų auksinių standartų - spirometrijos ir didelès raiškos KT rezultatais [25] vaikams [6] ir suaugusiesiems [26].

Dirbtinės plaučių ventiliacijos (toliau - DPV) komplikacijų nustatymas tinkamu laiku yra labai svarbus, siekiant išvengti grèsmès paciento būklei. EIT realiu laiku leidžia nustatyti regioninius ventiliacijos pokyčius, kurie atsiranda ivykus pneumotoraksui, atelektazei, esant netinkamai intubacinio vamzdžio padèčiai, susikaupus oro ar skysčio pleuros ertmeje [27]. Naudojantis jau sukurtais algoritmais [28], diagnozuojant pneumotoraksą, galima pasiekti 100 proc. jautrumą net ir esant nedideliam $(20 \mathrm{ml})$ oro kiekiui pleuros ertméje.

\section{Klinikinis EIT taikymas naujagimiams}

Nors EIT jau senokai naudojama suaugusiems ir vidurinio amžiaus vaikams bei paaugliams, naujagimiams ji pradèta taikyti visiškai neseniai [29]. Dèl technologinès 
pažangos, pasiūliusios sumažintus impedanso jutiklius, šiuolaikiški EIT prietaisai gali būti sèkmingai naudojami ir naujagimiams.

Naujagimių kvėpavimo takai yra gerokai siauresni, nei vidurinio amžiaus vaikų, paauglių ar suaugusiųjų, ypač trapūs ir linkę subliūkšti dèl krūtinès ląstos elastinių savybių ir mažo liekamojo plaučių tūrio [30]. Greta šių anatominių ypatumų, kvėpavimo takuose susikaupęs sekretas, o neišnešiotų naujagimių dar ir surfaktanto trūkumas, dažnai lemia nevienalytę plaučių aeraciją, siejamą su nepakankama ventiliacija ir oksigenacija. Dẻl šių priežasčių ypač svarbu naujagimiams parinkti saugų ir efektyvų kvėpuojamosios terapijos būdą, užtikrinantị tolygią plaučių ventiliaciją ir pakankamą kvèpuojamajị tūrį. Iki šiol nebuvo metodų, galinčių dinamiškai vertinti naujagimio plaučių būklę, plaučių kvépuojamajji tūrị ar optimalų iškvèpimo pabaigos slègi, neleidžiantį plaučiams subliūkšti ir palaikantị liekamajji plaučiu tūrị. EIT metodas teikia galimybę ne tik dinamiškai stebèti naujagimio plaučių pokyčius, bet ir parinkti tinkamiausią pagalbinio kvėpavimo būdą ar režimą.

Kvėpavimo sutrikimo sindromas (toliau - KSS) - tai naujagimių kvėpavimo sutrikimas dèl plaučių struktūros nebrandumo ir surfaktanto trūkumo. KSS dažnis yra tiesiogiai susijęs su néštumo trukme. Kuo anksčiau laiko gimsta naujagimis, tuo dažnesnis KSS: $<28$ gestacijos savaičių naujagimiams šis sindromas būna $>80$ proc. nuo visų atvejų [31], o išnešiotiems $-<1$ proc. [32]. Svarbiausi KSS gydymo komponentai yra egzogeninio surfaktanto skyrimas bei laiku pradèta kvejpuojamoji terapija. I trachèją sušvirkštas surfaktantas padeda alveolèms atsiverti, labai greitai pakeisdamas plaučių aeraciją ir elastines savybes. Siekiant išvengti plaučių pažeidimo, būtent šiuo laikotarpiu ypač svarbu deramai ịvertinti dinamiškai besikeičiančias plaučių savybes, tinkamai parinkti kvèpuojamosios terapijos būdą ir (arba) režimą. Iki šiol taikyti netiesioginiai plaučių kvėpuojamosios funkcijos vertinimo metodai, tokie kaip kraujo dujų tyrimas, pulsinè oksimetrija, transkutaninis $\mathrm{pCO}_{2}$ ir $\mathrm{pO}_{2}$ matavimas, $\mathrm{CO}_{2}$ kiekio iškvepiamose dujose matavimas ir kt. tik netiesiogiai ir tik tam tikru momentu atspindejjo plaučių būklę, tačiau neparodè plaučiuose vykstančių struktūrinių ir funkcinių pokyčių. Skirtingai nei suaugusiujų ARDS, naujagimių KSS būdingi homogeniški plaučiu pokyčiai [33], todèl plaučių dalių ventiliacijos registravimas ir vertinimas EIT metodu iš dalies atspindi plaučių visumos būklę. EIT padeda nustatyti mažiau ar labiau aeruojamas plaučių dalis, anksti praneša klinicistui apie plaučių ventiliacijos nevienalytiškumą, padedama koreguoti kvejpuojamają terapiją ir išvengti galimų komplikacijų net ir tais atvejais, kai naujagimio kvèpavimo nepakankamumas nèra akivaizdžiai išreikštas.

Naujagimių stebėjimas EIT parodè, kad surfaktanto sky- rimas didina plaučių liekamajji tūrị $[34,35]$, gerina oksigenaciją, mažina plaučiu pasipriešinimą plètimuisi, trumpina laiką ịkvèpimo tūriui pasiekti, ar didina ịkvėpimo tūrị [3]. Remiantis ankstesniais tyrimais manyta, jog surfaktanto poveikis pasireiškia praejjus 1 valandai nuo jo sušvirkštimo i trachejją, tačiau EIT parode, kad gydymo efektas yra greitas ir statistiškai reikšmingai pasikeičia po 5 minučių.

Didelio dažnio osciliuojančios ventiliacijos (toliau DDOV) stebėsena. $2006 \mathrm{~m}$. pasirodè pirmieji sėkmingi DDOV stebėsenos su EIT bandymai. Tam tikslui buvo sukurtas matematinis filtras, gebantis atskirti ventiliatoriaus sukeltus ịpūtimus nuo paciento spontaninio kvèpavimo [36]. EIT metodu buvo parodyta, kaip egzogeninio surfaktanto skyrimas kartu su DDOV pagerina neišnešiotų naujagimių plaučių aeraciją ir kvèpuojamajji tūrį [34]. A. H. van Kaam tyrejų grupe EIT metodu parodè neišnešiotų naujagimių, sergančių KSS, didelio dažnio osciliuojančios ventiliacijos ypatumus, atliekant oro talpos plaučiuose didinimo (angl. lung recruitment) procedūrą [33]. EIT taip pat padèjo ịrodyti plaučių histerezę taikant DDOV neišnešiotiems, KSS gydomiems naujagimiams bei jos skirtumus nuo suaugusiujjų ARDS [37].

Kūno padėties ịtaka ventiliacijai. Sergantiems naujagimiams, ypač neišnešiotiems, būdingi nesinchronizuoti krūtinès ląstos ir pilvo kvèpavimo judesiai, vadinamoji torako-abdominalinė asinchronija [38]. EIT pagalba galima nustatyti ir parinkti tokią naujagimio gulejimo pozą, kurioje vienos ar kitos plaučiu dalys yra geriausiai aeruojamos. To prie ligonio lovos neimanoma padaryti kitais metodais. Siekiant sinchronizuoti krūtinès ląstos ir pilvo judesius ir taip pagerinti plaučių ventiliaciją, naujagimis dažniausiai guldomas ant pilvo - tokia padètis dažnai pagerina oksigenaciją (saturaciją) ir padidina funkcinị liekamajị plaučių tūrị [39]. EIT tyrimai parodè, jog gulint ant pilvo geriausiai ventiliuojamos dorsalinès plaučių dalys, kurios ịprastai veikiamos gravitacijos jègos [40]. Žinoma, kad ant pilvo gulinčio naujagimio ar kūdikio padètis gali sukelti ir nepageidaujamų reiškinių, tokių kaip poodinè periorbitalinè edema, ragenos abrazijos ar staigios kūdikių mirties sindromas, todèl buvo ieškoma tarpinès gulimosios padèties, kuri neturètų anksčiau išvardytų neigiamų padarinių, išsaugant teigiamas ypatybes. EIT parodè, jog pusiau kniūpsčia padètis taip pat efektyviai pagerina oksigenaciją ir funkcinį liekamajị plaučių tūrị, kartu sumažindama kvėpavimo dažni [41].

DPV komplikacijų nustatymas. Atliekant dirbtinị kvèpavimą, naujagimiams galimos tokios pat komplikacijos, kaip ir vidutinio amžiaus vaikams, paaugliams ar suaugusiems: pnemotoraksas, hidrotoraksas, atelektazè, netinkama intubacinio vamzdelio padètis [42-44]. Nuolatinè sunkiai sergančių ar neišnešiotų naujagimių regioninès ventiliacijos 
stebėsena EIT pagalba gali padèti išvengti kvėpavimo aparato ir dirbtinio kvẻpavimo sukeliamo plaučių pažeidimo (angl. ventilator associated lung injury, sutr. VALI) [45].

\section{Išvados}

EIT, pradèta naudoti mokslinių tyrimų srityje, sparčiai diegiama klinikinèje praktikoje. EIT taikymas plinta visoms pacientų amžiaus grupèms, nes šis tyrimo metodas galimas prie paciento lovos, neskleidžia jonizuojančios radiacijos, užtikrina pakankamą vaizdų kokybę realiuoju laiku, leidžia individualizuoti paciento, turinčio kvẻpavimo problemų, medicininę priežiūrą [46]. Tai ypač svarbu ligoniams, kurių plaučiai pažeidžiami nehomogeniškai (pvz., ARDS) ir kurie sudaro nevienalytę grupę, kai negalima bendroji kvèpuojamosios pagalbos strategija. EIT teikiama informacija padeda parinkti ligoniui tinkamesnę plaučių ventiliavimo strategiją, negu numatytoji standartizuotuose ARDS protokoluose [47]. Tokiems pacientams labai svarbu parinkti optimalų PEEP, kuris garantuotų geriausią oksigenaciją, kuo mažiau pažeidžiant plaučius. EIT prietaiso naudojimo algoritmai ir(ar) automatinis PEEP titravimas padeda pasiekti šị tikslą.

Sergant lètinėmis plaučių ligomis, EIT padeda geriau suprasti plaučiu patologinius procesus, nuolat ir saugiai stebèti ligonių kvèpavimo sistemos būklę, vertinti ligos eigą ir atsaką i gydymą.

EIT vis plačiau taikoma naujagimiams. EIT informacija yra labai vertinga stebèti ir suprasti KSS sukeltus pokyčius plaučiuose, po gydymo surfaktantu ir taikant įvairius pagalbinio kvèpavimo būdus ar režimus. EIT teikia galimybę ịvertinti regioninę plaučių ventiliaciją realiuoju laiku, padeda parinkti optimalią kvépuojamają terapiją, laiku nustatyti galimas ar jau įvykusias komplikacijas.

Greta nurodytų privalumų, EIT tyrimas turi ir trūkumų. EIT vaizdų raiškai turi įtakos jutiklių kontaktas su oda, todèl, pacientui judant, gali nukenteti vaizdo kokybè. Diržas su elektrodais negali būti dedamas ant pažeistos odos dèl galimo infekcijos pavojaus ar papildomo pažeistos vietos dirginimo. EIT taikant nutukusiems pacientams (KMI >50), kurių riebalinè masė lemia prastesnį laidumą, nukenčia vaizdo kokybė. EIT nerekomenduojama stuburo traumą patyrusiems pacientams, nes dedant ar keičiant diržą su elektrodais, reikia keisti ligonio padètį. EIT negalima ligoniams su implantuotu elektriniu širdies stimuliatoriumi, nes prietaiso veikla gali sutrikdyti širdies stimuliatoriaus darbą. Gaunamų vaizdų interpretavimui reikalingas tinkamas pasiruošimas ir patirtis, o EIT aparatas brangus, todèl iki šiol EIT dažniausiai naudojamas tuose medicinos centruose, kuriuose gydomi sunkiai sergantys (ypač kvėpavimo ligomis) ligoniai, reikalingi individualizuotos kvėpuojamosios terapijos.

\section{Literatūra}

1. Barber DC, Brown BH. Applied potential tomography. J Phys E 1984;17(9):723-733. https://doi.org/10.1088/0022-3735/17/9/002

2. Long Y, Liu DW, He HW, Zhao ZQ. Positive end-expiratory pressure titration after alveolar recruitment directed by electrical impedance tomography. Chin Med J (Engl) 2015;128(11):1421-1427. https://doi.org/10.4103/0366-6999.157626

3. Miedema M, de Jongh FH, Frerichs I, van Veenendaal MB, van Kaam AH. Regional respiratory time constants during lung recruitment in high-frequency oscillatory ventilated preterm infants. Intensive Care Med 2012;38(2):294-299.

https://doi.org/10.1007/s00134-011-2410-2

4. Becher TH, Bui S, Zick G, et al. Assessment of respiratory system compliance with electrical impedance tomography using a positive end-expiratory pressure wave maneuver during pressure support ventilation: a pilot clinical study. Crit Care 2014;18(1):1-11.

https://doi.org/10.1186/s13054-014-0679-6

5. Vogt B, Pulletz S, Elke G, et al. Spatial and temporal heterogeneity of regional lung ventilation determined by electrical impedance tomography during pulmonary function testing. J Appl Physiol 2012;113(7):1154-1161.

https://doi.org/10.1152/japplphysiol.01630.2011

6. Vogt B, Löhr S, Zhao Z, et al. Regional lung function testing in children using electrical impedance tomography. Pediatr Pulmonol 2018;53(3):293-301.

https://doi.org/10.1002/ppul.23912

7. Bodenstein M, David M, Markstaller K. Principles of electrical impedance tomography and its clinical application. Crit Care Med 2009;37(2):713-724. https://doi.org/10.1097/CCM.0b013e3181958d2f

8. Frerichs I, Amato MBP, van Kaam AH, et al. Chest electrical impedance tomography examination, data analysis, terminology, clinical use and recommendations: consensus statement of the Translational EIT development study group. Thorax. 2016;72(1):83-93. doi:10.1136/thoraxjnl-2016-208357 https://doi.org/10.1136/thoraxjnl-2016-208357

9. Frerichs I, Hinz J, Herrmann P, et al. Regional lung perfusion as determined by electrical impedance tomography in comparison with electron beam CT imaging. IEEE Trans Med Imaging 2002;21(6):646-652.

https://doi.org/10.1109/TMI.2002.800585

10. Davies P, Yasin S, Gates S, Bird D, Silvestre C. Clinical scenarios of the application of electrical impedance tomography in paediatric intensive care. Sci Rep 2019;9(1):5362. https://doi.org/10.1038/s41598-019-41774-1

11. Teschner E, Imhoff M, Leonhardt S. Electrical impedance tomography: the realisation of regional ventilation monitoring, 2nd ed. Lübeck: Drägerwerk AG \& Co. KGaA, 2015.

12. Elke G, Fuld MK, Halaweish AF, et al. Quantification of 
ventilation distribution in regional lung injury by electrical impedance tomography and xenon computed tomography. Physiol Meas 2013;34(10):1303-1318.

https://doi.org/10.1088/0967-3334/34/10/1303

13. Victorino JA, Borges JB, Okamoto VN, et al. Imbalances in regional lung ventilation. Am J Respir Crit Care Med 2003;169(7):791-800.

https://doi.org/10.1164/rccm.200301-133OC

14. Beitler JR, Sarge T, Banner-Goodspeed VM, et al. Effect of titrating positive end-expiratory pressure (PEEP) with an esophageal pressure-guided strategy vs an empirical high PEEP-Fio 2 strategy on death and days free from mechanical ventilation among patients with acute respiratory distress syndrome: a randomized clinical trial. Jama 2019;321(9):846-857. https://doi.org/10.1001/jama.2019.0555

15. Grivans C, Lundin S, Stenqvist O, Lindgren S. Positive endexpiratory pressure-induced changes in end-expiratory lung volume measured by spirometry and electric impedance tomography. Acta Anaesthesiol Scand 2011;55(9):1068-1077. https://doi.org/10.1111/j.1399-6576.2011.02511.x

16. Reifferscheid F, Elke G, Pulletz S, et al. Regional ventilation distribution determined by electrical impedance tomography: reproducibility and effects of posture and chest planeresp. Respirology 2011;16(3):523-531.

https://doi.org/10.1111/j.1440-1843.2011.01929.x

17. Fanelli V, Vlachou A, Ghannadian S, Simonetti U, Slutsky AS, Zhang H. Acute respiratory distress syndrome: new definition, current and future therapeutic options. J Thorac Dis 2013;5(3):326-334.doi:10.3978/j.issn.2072-1439.2013.04.05

18. Amato MBP, Meade MO, Slutsky AS, et al. Driving pressure and survival in the acute respiratory distress syndrome. N Engl J Med 2015;372(8):747-755.

https://doi.org/10.1056/NEJMsa1410639

19. Pulletz S, Kott M, Elke G, et al. Dynamics of regional lung aeration determined by electrical impedance tomography in patients with acute respiratory distress syndrome. Multidiscip Respir Med 2012;7(6):1-9.

https://doi.org/10.1186/2049-6958-7-44

20. Pereira SM, Tucci MR, Morais CCA, et al. Individual positive end-expiratory pressure settings optimize intraoperative mechanical ventilation and reduce postoperative atelectasis. Anesthesiology 2018;129(6):1070-1081. https://doi.org/10.1097/ALN.0000000000002435

21. Sakalauskas R.(sudarytojas), Danila E., Zablockis R., Bagdonas A., Zolubas M. Suaugusiujuc pneumonijos diagnostika ir gydymas. Lietuvos pulmonologų sutarimas. Kaunas, 2016:58.

22. Welte T, Torres A, Nathwani D. Clinical and economic burden of community-acquired pneumonia among adults in Europe. Thorax 2012;67(1):71-79.

https://doi.org/10.1136/thx.2009.129502

23. Karsten J, Krabbe K, Heinze H, Dalhoff K, Meier T, Drömann D. Bedside monitoring of ventilation distribution and alveolar inflammation in community-acquired pneumonia. J Clin Monit
Comput 2014;28(4):403-408.

https://doi.org/10.1007/s10877-014-9549-7

24. Malakauskas K., Sakalauskas R., Danila E., Zablockis R. Lietuvos suaugusiujų cistinès fibrozès diagnostikos, gydymo ir pagalbos organizavimo sutarimas. Pulmonologija, imunologija ir alergologija, 2011;1(8):2-12.

25. Zhao Z, Müller-Lisse U, Frerichs I, Fischer R, Möller K. Regional airway obstruction in cystic fibrosis determined by electrical impedance tomography in comparison with high resolution CT. Physiol Meas 2013;34(11).

https://doi.org/10.1088/0967-3334/34/11/N107

26. Zhao Z, Fischer R, Frerichs I, Müller-Lisse U, Möller K. Regional ventilation in cystic fibrosis measured by electrical impedance tomography. J Cyst Fibros 2012;11(5):412-418. doi:10.1016/j.jcf.2012.03.011 https://doi.org/10.1016/j.jcf.2012.03.011

27. Becher T, Bußmeyer M, Lautenschläger I, Schädler D, Weiler N, Frerichs I. Characteristic pattern of pleural effusion in electrical impedance tomography images of critically ill patients. Br J Anaesth 2018;120(6):1219-1228.

https://doi.org/10.1016/j.bja.2018.02.030

28. Costa ELV, Chaves CN, Gomes S, et al. Real-time detection of pneumothorax using electrical impedance tomography. Crit Care Med 2008;36(4):1230-1238.

https://doi.org/10.1097/CCM.0b013e31816a0380

29. Seppä V-P. Development and clinical application of impedance pneumography technique. Tampere university of technology 2014;1253:122.

30. Mansell A, Bryan C, Levison H. Airway closure in children. J Appl Physiol 1972;33(6):711-714.

https://doi.org/10.1152/jappl.1972.33.6.711

31. Laptook AR, Walsh MC, Hale EC, Poindexter BB, Finer NN, Richard A. Neonatal outcome of extremely preterm infants from the NICHD research network. Pediatrics 2010;126(3):443-456. https://doi.org/10.1542/peds.2009-2959

32. Wickersham IR, Lyon DC, Barnard RJO, et al. NIH public access. Young. 2009;53(5):639-647.

https://doi.org/10.1016/j.neuron.2007.01.033

33. Miedema M, de Jongh FH, Frerichs I, van Veenendaal MB, van Kaam AH. The effect of airway pressure and oscillation amplitude on ventilation in preterm infants. Eur Respir J 2012;40(2):479-484.

https://doi.org/10.1183/09031936.00138311

34. Miedema M, de Jongh FH, Frerichs I, van Veenendaal MB, van Kaam AH. Changes in lung volume and ventilation during surfactant treatment in ventilated preterm infants. Am J Respir Crit Care Med 2011;184(1):100-105. https://doi.org/10.1164/rccm.201103-0375OC

35. van der Burg PS, de Jongh FH, Miedema M, Frerichs I, Van Kaam AH. Effect of minimally invasive surfactant therapy on lung volume and ventilation in preterm infants. J Pediatr 2016;170:67-72. 
https://doi.org/10.1016/j.jpeds.2015.11.035

36. Dunlop S, Hough J, Riedel T, Fraser JF, Dunster K, Schibler A. Electrical impedance tomography in extremely prematurely born infants and during high frequency oscillatory ventilation analyzed in the frequency domain. Physiol Meas 2006;27(11). https://doi.org/10.1088/0967-3334/27/11/008

37. Miedema M, de Jongh FH, Frerichs I, van Veenendaal MB, van $\mathrm{Kaam} \mathrm{AH}$. Changes in lung volume and ventilation during lung recruitment in high-frequency ventilated preterm infants with respiratory distress syndrome. J Pediatr 2011;159(2). https://doi.org/10.1016/j.jpeds.2011.01.066

38. Wolfson MR, Greenspan JS, Deoras KS, Allen JL, Shaffer $\mathrm{TH}$. Effect of position on the mechanical interaction between the rib cage and abdomen in preterm infants. J Appl Physiol 1992;72(3):1032-1038. https://doi.org/10.1152/jappl.1992.72.3.1032

39. Gouna G, Rakza T, Kuissi E, Pennaforte T, Mur S, Storme L. Positioning effects on lung function and breathing pattern in premature newborns. J Pediatr 2013;162(6):1133-1137.e1. https://doi.org/10.1016/j.jpeds.2012.11.036

40. van der Burg PS, Miedema M, de Jongh FH, Frerichs I, van Kaam AH. Changes in lung volume and ventilation following transition from invasive to noninvasive respiratory support and prone positioning in preterm infants. Pediatr Res 2015;77(3):484-488.

https://doi.org/10.1038/pr.2014.201

41. Montgomery K, Choy NL, Steele M, Hough J. The effectiveness of quarter turn from prone in maintaining respiratory function in premature infants. J Paediatr Child Health 2014;50(12):972977.

https://doi.org/10.1111/jpc.12689

42. Miedema M, Frerichs I, de Jongh FHC, van Veenendaal MB, van Kaam AH. Pneumothorax in a preterm infant monitored by electrical impedance tomography: a case report. Neonatology 2010;99(1):10-13.

https://doi.org/10.1159/000292626

43. van der Burg PS, Miedema M, de Jongh FH, van Kaam AH. Unilateral atelectasis in a preterm infant monitored with electrical impedance tomography: a case report. Eur J Pediatr 2014;173(12):1715-1717.

https://doi.org/10.1007/s00431-014-2399-y

44. Steinmann D, Engehausen M, Stiller B, Guttmann J. Electrical impedance tomography for verification of correct endotracheal tube placement in paediatric patients: a feasibility study. Acta Anaesthesiol Scand 2013;57(7):881-887.

https://doi.org/10.1111/aas.12143
45. Miedema M, Waldmann A, McCall KE, Böhm SH, van Kaam $\mathrm{AH}$, Tingay DG. Individualized multiplanar electrical impedance tomography in infants to optimize lung monitoring. Am J Respir Crit Care Med 2017;195(4):536-538. https://doi.org/10.1164/rccm.201607-1370LE

46. Durlak W, Kwinta P. Role of electrical impedance tomography in clinical practice in pediatric respiratory medicine. ISRN Pediatr 2013;2013:1-5. https://doi.org/10.1155/2013/529038

47. Theerawit P, Sutherasan Y, Ball L, Pelosi P. Respiratory monitoring in adult intensive care unit. Expert Rev Respir Med 2017;11(6):453-468.

https://doi.org/10.1080/17476348.2017.1325324

\section{FUNCTIONAL LUNG IMAGING USING ELECTRICAL IMPEDANCE TOMOGRAPHY: CLINICAL APPLICATIONS}

E. Viršilas, A. Janulionis, A. Liubšys, A. Valiulis

Keywords: electrical impedance tomography, mechanical ventilation, acute (adult) respiratory distress syndrome, neonatal respiratory distress syndrome, neonate.

Summary

Introduction: Electric impedance tomography (EIT) is a relatively new, non-invasive, real-time imaging technique that allows for the evaluation and monitoring of pulmonary aeration at bedside. For a long time, indirect or invasive methods have been used to assess respiratory lung function, all of which lack precision, temporal resolution and/or emit ionizing radiation. With the advancement of EIT technology, this imaging modality is gaining popularity not only among adults and older children, but is also finding its way into the daily practice of neonatal treatment and care.

Objective: To raise awareness of the EIT approach and its application in clinical practice. Methodology: an electronic search of Pubmed was performed up to August 2019 about EIT and its application for humans.

Conclusions: EIT provides real-time information on regional lung aeration, which helps identify pulmonary changes and provides timely, patient specific respiratory therapy. It can aid in the timely detection and resolution of acute complications as well as provide valuable information on chronic lung diseases, their treatment and possible outcome.

Correspondence to: ernestas.virsilas@santa.It

Gauta 2019-11-15 